\title{
Resiko Kejadian Asfiksia Neonatorum pada Ketuban Pecah Dini di Rumah Sakit Kalisat Jember
}

\author{
Jenie Palupi ${ }^{1}$, Syiska Atik Maryanti ${ }^{2}$ \\ Poltekkes Kemenkes Malang Prodi Kebidanan Jember \\ E-mail: syiska_hermawan@yahoo.com
}

\begin{abstract}
Abstrak
Ketuban pecah dini adalah keluarnya cairan ketuban dari jalan lahir sebelum ada tanda-tanda persalinan. Ketuban pecah dini merupakan salah satu faktor penyebab terjadinya asfiksia neonatorum karena akibat dari adanya penekanan pada tali pusat di dalam kandungan sehingga bayi mengalami gangguan pertukaran $\mathrm{O} 2$ dan berlanjut menjadi asfiksia. Tujuan penelitian mengetahui ada resiko kejadian asfiksia neonatorum pada ketuban pecah dini di Rumah Sakit Kalisat Jember. Desain penelitian analisis korelasi dengan pendekatan case control, jumlah sampel 69 responden menggunakan data sekunder rekam medik RS Kalisat Jember bulan Oktober Desember 2017 dan dianalisa dengan uji chi square, Koefisien Kontingensi dan odd ratio. Hasil penelitian terdapat $42,02 \%$ ketuban pecah dini dan bayi yang mengalami asfiksia sebesar $31,88 \%$. Analisa menggunakan chi square didapatkan X2 hitung sebesar 20,987 > X2 tabel sebesar 3,841 dan Koefisien Kontingensi 0,483 artinya ada hubungan yang cukup kuat. Analisa menggunakan odd ratio didapatkan nilai 14,727 artinya ada resiko (efek negatif). Kesimpulan ada hubungan antara ketuban pecah dini dengan asfiksia neonatorum dan ada resiko kejadian asfiksia neonatorum pada ketuban pecah dini Sebaiknya bagi tenaga kesehatan di rumah sakit untuk melakukan pelayanan dan perawatan yang konservatif pada ibu bersalin yang mengalami ketuban pecah dini sehingga dapat mengurangi resiko terjadinya asfiksia pada bayi baru lahir.
\end{abstract}

Key words: Resiko Kejadian Asfiksia, Ketuban Pecah Dini

\section{Abstract}

Early rupture of membranes is the release of amniotic fluid from the birth canal before any signs of labor. Early rupture of membranes is one of the factors causing asphyxia neonatorum because of the emphasis on the umbilical cord in the womb so that the baby has an $\mathrm{O} 2$ exchange disorder and continues to be asphyxia. The objective of the study was to know the risk of asphyxia neonatorum occurrence on premature rupture of membranes at Kalisat Hospital. The research design of correlation analysis with case control approach, the sample number of 69 respondents use secondary data of Kalisat Jember Hospital Hospital from October to December 2017 and analyzed by chi square test, Contingency Coefficient and odd ratios. The result showed $42.02 \%$ of premature rupture and infant with asphyxia 31,88\%. Analysis using chi square got X2 count equal to 20,987> X2 table equal to 3,841 and Contingency Coefficient 0,483 meaning there is relationship strong enough. Analysis using odd ratio got value 14,727 meaning there is risk (negative effect). Conclusion There is a relationship between premature rupture of membranes with asphyxia neonatorum and there is a risk of asphyxia neonatorum occurrence in premature rupture of membranes. Preferably for health workers in hospitals to perform services and conservative care in mothers who experience premature rupture of membranes so as to reduce the risk of asphyxia in newborns.

Key words: Risk of Asphyxia Occurrence, Premature rupture of membranes

\section{Pendahuluan}

Saat ini angka kematian neonatus di Indonesia masih cukup tinggi yaitu sebesar 19 kematian per 1.000. Menurut Depkes RI (2015) neonatal dengan komplikasi adalah neonatal dengan penyakit atau kelainan yang dapat menyebabkan kematian atau kecacatan. Komplikasi yang menjadi penyebab kematian terbanyak yaitu asfiksia neonatorum (27\%). Asfiksia neonatorum termasuk ke dalam resiko tinggi kelahiran neonatus yang menjadi salah satu penyebab kematian bayi baru lahir (Dewi, 2014: 11). Menurut Sukarni (2014: 159) Asfiksia neonatorum merupakan kegagalan untuk memulai dan melanjutkan pernapasan secara spontan dan teratur pada saat bayi baru lahir atau beberapa saat sudah lahir.

Adapun faktor penyebab terjadinya asfiksia neonatorum yaitu faktor ibu, faktor tali pusat, faktor plasenta, dan faktor janin. Faktor ibu yaitu preeklampsia/eklampsia, partus lama, perdarahan antepartum, kehamilan post matur, demam selama persalinan, dan ketuban pecah dini. Faktor tali pusat yaitu plasenta previa dan solusio plasenta. Faktor janin yaitu prematur, persalinan sulit, kelainan kongenital dan air ketuban bercampur dengan mekonium. Sedangkan faktor tali pusat yang dapat menyebabkan asfiksia yaitu prolapsus tali pusat, tali pusat pendek, lilitan tali pusat, simpul tali pusat, torsi tali pusat, dan tekanan pada tali pusat yang menyebabkan gangguan pertukaran gas dari ibu ke janin terganggu sehingga terjadi asfiksia pada bayi baru lahir. Kompresi tali pusat ini terjadi akibat ketuban pecah dini (Mochtar, 1998).

Ketuban pecah dini adalah keluarnya cairan dari jalan lahir atau vagina sebelum 
proses persalinan (Rahmawati, 2011: 127). Dalam keadaan normal 8-10 \% perempuan hamil aterm akan mengalami ketuban pecah dini (Prawirohardjo, 2008: 677).

Ketuban pecah dini akan mengakibatkan terjadinya oligohidramnion, kondisi ini akan mempengaruhi janin karena sedikitnya volume air ketuban akan menyebabkan tali pusat tertekan oleh bagian tubuh janin akibatnya aliran darah dari ibu ke janin berkurang sehingga bayi mengalami hipoksia atau gangguan pertukaran oksigen (O2) sehingga fetal distress dan berlanjut menjadi asfiksia pada bayi baru lahir (Prawirohardjo, 2008: 679). Dalam penelitian ini ingin diketahui adanya resiko kejadian asfiksia neonatorum pada ketuban pecah dini di Rumah Sakit Kalisat.

\section{Metode Penelitian}

Penelitian ini merupakan penelitian yang menggunakan pendekatan case control (kasus kontrol). Populasi penelitian sebanyak 84 ibu bersalin, sampling menggunakan random sampling dengan jumlah sampel sebanyak 69 responden ibu bersalin yang memenuhi kriteria inklusi. Instrumen penelitian mengunakan data rekam medik responden.

\section{Hasil Dan Pembahasan}

Hasil

Pada bab ini membahas mengenai hasil penelitian dan pembahasan tentang "Resiko Kejadian Asfiksia Neonatorum Pada Ketuban Pecah Dini Di Rumah Sakit Kalisat Jember". Jumlah responden berdasarkan kriteria inklusi sebanyak 69 responden. Data yang diperoleh berupa data khusus, kemudian disajikan dalam bentuk tabel distribusi. Dari data penelitian yang dilaksanakan maka diperoleh data sebagai berikut.

Asfiksia Neonatorum

Tabel 1. Distribusi frekuensi asfiksia neonatorum di RS Kalisat Jember.

\begin{tabular}{ccc}
\hline Asfiksia & Jumlah & $\begin{array}{c}\text { Presentase } \\
(\%)\end{array}$ \\
\hline Ya & 22 & $31,88 \%$ \\
\hline Tidak & 47 & $68,11 \%$ \\
\hline Jumlah & 69 & $100,0 \%$ \\
\hline
\end{tabular}

Sumber: Data Sekunder 2017

Berdasarkan Tabel 1 diketahui bahwa dari 69 responden yang didapatkan sebagian besar bayi dari responden dengan tidak asfiksia sebanyak $47(68,11 \%)$ bayi.

Ketuban Pecah Dini (KPD)

Tabel 2. Distribusi frekuensi ketuban pecah dini (KPD) di RS Kalisat Jember.

KPD Jumlah Presentase (\%)

\begin{tabular}{ccc}
\hline Ya & 29 & $42,02 \%$ \\
\hline Tidak & 40 & $57,97 \%$ \\
\hline Jumlah & 69 & $100,0 \%$ \\
\hline
\end{tabular}

Sumber: Data Sekunder 2017

Berdasarkan Tabel 2 diketahui bahwa dari 69 responden yang didapatkan sebagian besar responden dengan tidak KPD sebanyak $40(57,97 \%)$ responden.

\section{Analisa data hubungan ketuban pecah dini dengan asfiksia neonatorum}

Tabel 3. Tabel silang hubungan ketuban pecah dini dengan asfiksia neonatorum Di Rumah Sakit Kalisat Jember.

\begin{tabular}{cccc}
\hline \multirow{2}{*}{ KPD } & \multicolumn{2}{c}{ Asfiksia } & Total \\
& Ya & Tidak & \\
\hline Ya & 18 & 11 & 29 \\
Tidak & 4 & 36 & 40 \\
\hline Total & 22 & 47 & 69
\end{tabular}

Sumber: Data Sekunder 2017

Berdasarkan Tabel 3 diketahui bahwa dari 69 responden yang didapatkan bahwa ibu bersalin dengan ketuban pecah dini (KPD) yang melahirkan bayi asfiksia sebanyak 18 $(26,08 \%)$ responden, ibu bersalin dengan ketuban pecah dini (KPD) yang melahirkan bayi tidak asfiksia sebanyak 11 (15,94\%) responden, ibu bersalin dengan tidak ketuban pecah dini (KPD) yang melahirkan bayi asfiksia sebanyak $04(5,79 \%)$ responden, dan ibu bersalin dengan tidak (KPD) melahirkan bayi tidak asfiksia sebanyak $36 \quad(52,17 \%)$ responden.

Berdasarkan hasil penelitian dari 69 responden dilakukan perhitungan pada SPSS didapatkan modusnya adalah ibu bersalin dengan tidak KPD dan bayi baru lahir tidak mengalami asfiksia.

Setelah dianalisa dengan perhitungan SPSS mengunakan uji chi square diperoleh $x^{\wedge} 2$ hitung sebesar 20,987 . Pada hasil $x^{\wedge} 2$ tabel dengan $\mathrm{dk}=1$ dan taraf kesalahan $5 \%$ diketahui sebesar 3,841. Selanjutnya keduanya dibandingkan sehingga $x^{\wedge} 2$ hitung $>$ $x^{\wedge} 2$ tabel, maka hipotesa nihil ditolak dan hipotesa kerja diterima, yang artinya ada hubungan antara ketuban pecah dini dengan asfiksia neonatorum.

Lalu dari hasil analisis diketahui nilai asymp.sig adalah 0,001 dimana nilai tersebut lebih kecil dari nilai $\alpha=5 \%$. Selanjutnya dapat dilakukan analisa keeratan hubungan dengan hasil 0,483 yang berarti pada rentang korelasi cukup kuat.

Dari hasil perhitungan SPSS dengan menggunakan uji chi square bisa dilanjutkan untuk perhitungan odd ratio. Berdasarkan hasil perhitungan SPSS menggunakan odd ratio 
didapatkan nilai sebesar 14,727 yang hasilnya $>1$ maka berarti ada efek negative yang artinya ibu bersalin dengan KPD lebih beresiko $14 \mathrm{kali}$ lipat daripada ibu bersalin yang tidak KPD untuk melahirkan bayi yang asfiksia.

\section{Pembahasan}

\section{Kejadian Asfiksia Neonatorum Pada Ketuban Pecah Dini Di Rumah Sakit Kalisat Jember}

Berdasarkan hasil penelitian dari 69 responden didapatkan hasil bahwa sebagian besar $47(68,11 \%)$ responden dengan tidak asfiksia dan $22(31,88 \%)$ responden yang mengalami asfiksia. Asfiksia neonatorum adalah suatu keadaan bayi baru lahir yang gagal bernafas secara spontan dan teratur segera setelah lahir (Sondakh, 2013:176). Secara umum banyak faktor yang dapat menyebabkan asfiksia pada bayi baru lahir, yaitu dari faktor ibu, faktor janin, faktor plasenta dan faktor tali pusat.

Dalam penelitian ini didapatan hasil bahwa ibu yang melahirkan bayi dengan asfiksia neonatorum sebagian besar karena kejadian ketuban pecah dini (KPD). Persalinan dengan ketuban pecah dini merupakan salah satu persalinan yang berisiko, dimana ketuban pecah sebelum ada tanda-tanda persalinan. Hal ini dapat menyebabkan terjadinya bahaya dan komplikasi yang lebih besar baik terhadap ibu maupun janin yang di kandung selama kehamilan dan saat melahirkan.

Setelah melahirkan, bayi yang lahir mengalami masa transisi dari intrauterine ke ekstrauterin menuju perubahan artinya bayi ketika dalam rahim mendapatkan oksigen melalui plasenta sedangkan saat bayi lahir, bayi mendapatkan asupan oksigen dengan usahanya sendiri. Apabila bayi tidak mendapatkan cukup oksigen dari usahanya maka bayi akan mengalami asfiksia ketika lahir. Adapun faktor lain yang dapat menyebabkan asfiksia neonatorum yaitu kurangnya cairan ketuban di dalam rahim maka dapat terjadi penekanan pada tali pusat yang menyebabkan gangguan pertukaran gas dari ibu ke janin terganggu sehingga terjadi asfiksia pada bayi baru lahir.

Saat terjadi adanya peluang asfiksia pada bayi baru lahir, bidan harus menyadari dari hal yang fisiologi bisa berpotensi menjadi hal yang patologis sehingga bidan perlu untuk mengantisipasinya dengan memberikan KIE yang sesuai pada saat kehamilan. Bidan memberikan KIE tentang tanda-tanda bahaya pada saat kehamilan salah satunya yaitu air ketuban keluar sebelum waktunya yang bisa berpontensi menjadi ketuban pecah dini (KPD). Bila ibu sudah menyadari tentang tanda-tanda bahaya saat kehamilan tersebut maka artinya ibu bisa melakukan deteksi dini sehingga tidak terjadi komplikasi pada ibu dan bayi dengan memeriksaan diri ke tenaga kesehatan. Berdasarkan hal tersebut dapat disimpulkan bahwa asfiksia neonatorum dapat dipengaruhi oleh faktor ibu terutama dengan indikasi ketuban pecah dini (KPD).

\section{Ketuban Pecah Dini (KPD) Di Rumah Sakit} Kalisat Jember

Berdasarkan hasil penelitian dari 69 responden didapatkan hasil bahwa sebagian besar $40(57,97 \%)$ responden dengan tidak KPD dan $29(42,02 \%)$ responden ibu bersalin dengan KPD. Ketuban pecah dini (KPD) adalah pecahnya selaput ketuban sebelum ada tanda-tanda persalinan (Sukarni, 2014 65). Menurut Prawirohardjo (2009) menyatsakan bahwa ketuban pecah dini (KPD) diakibatkan karena melemashnya kekuatan selaput ketuban sehingga terjadi perubahan biokimia pada selaput ketuban. Perubahan biokimia pada selaput ketuban terjadi di dalam kolagen matriks ekstra selular amnion, karion, dan apoptosis membran janin. Membran janin dan desidua bereaksi terhadap stimuli seperi infeksi dan peregangan selaput ketuban dengan memproduksi mediator seperti prostaglandin, sitokinin, dan protein hormon yang merangsang aktivitas. Berdasarkan dari 29 responden ibu bersalin dengan KPD, dapat dinyatakan bahwa ketuban pecah dalam persalinan secara umum disebabkan oleh kontraksi uterus dan peregangan berulang.

Pada selaput ketuban tersebut dapat menentukan semua kekuatan regangan membran janin, jika selaput robek maka tidak akan membungkus air ketuban dan akan membuka dorsal janin sehingga dapat menyebabkan mudahnya masuk mikroorganisme ke dalam rahim yang dapat menimbulkan resiko terjadinya infeksi pada bayi baru lahir dan dapat meningkatkan terjadinya pula asfiksia pada bayi baru lahir.

Kejadian ketuban pecah dini (KPD) dapat dipicu dari terjadinya adanya penurunan kandungan kolagen dalam membran. Ibu yang mengalami ketuban pecah dini pada kehamilan atau menjelang persalinan maka pada kehamilan berikutnya wanita yang telah mengalami ketuban pecah dini akan lebih beresiko mengalaminya kembali antara 3-4 kali daripada wanita yang tidak mengalami ketuban pecah dini sebelumnya, karena komposisi membran yang menjadi mudah rapuh dan kandungan kolagen yang semakin menurun pada kehamilan berikutnya (Cunningham, 2006).

Pada ibu bersalin yang mengalami ketuban pecah dini (KPD) jika mendapatkan 
penangaan yang lambat maka akan menyebabkan terjadinya asfiksia pada baru lahir karena kurangnya mengerti pada kejadian ketuban pecah dini atau terlambatnya dibawa ke rumah sakit, tidak ada kemajuan persalinan ketika pasien dilakukan tidakan konservatif dengan pemberian obat, dan ketika sudah di RS sering dilakukan pemeriksaan dalam sehingga dapat beresiko menyebabkan terjadinya infeksi. Berdasarkan hal tersebut dapat disimpulkan bahwa ketuban pecah dini dapat mempengaruhi terjadinya asfiksia neonatorum yang dipengaruhi oleh lemahnya kekuatan dari selaput ketuban.

Hubungan Antara Ketuban Pecah Dini Dengan Asfiksia Neonatorum Di Rumah Sakit Kalisat Jember.

Berdasarkan hasil dari SPSS mengunakan uji chi square $x^{\wedge} 2$ Hitung $>x^{\wedge} 2$ Tabel, maka hipotesa nihil ditolak dan hipotesa kerja diterima, yang artinya ada hubungan antara ketuban pecah dini dengan asfiksia neonatorum. Lalu dari hasil analisa keeratan hubungan (KK) dengan hasil 0,483 berarti ada rentang korelasi cukup kuat antara ketuban pecah dini (KPD) dengan asfiksia neonatorum.

Berdasarkan hasil penelitian ini diketahui bahwa ibu bersalin dengan KPD yang melahirkan bayi asfiksia sebanyak 18 $(26,08 \%)$ responden dan ibu bersalin dengan tidak KPD yang melahirkan bayi asfiksia sebanyak $4(5,79 \%)$ responden.

Hal diatas sesuai dengan teori menurut Rahmawati (2011:130) yang menyatakan bahwa ketuban pecah dini yang tidak dilakukan tindakan dengan cepat dapat menimbulkan resiko infeksi yang disebabkan karena tidak ada perlindungan dari dunia luar dengan daerah rahim sehingga mempermudah masuknya mikroorganisme ke dalam rahim. Saat hal itu terjadi maka ketika bayi baru lahir dapat mengakibatkan terjadinya asfiksia. Sedangkan menurut Prawirohardjo (2008:679) ketuban pecah dini akan mengakibatkan terjadinya oligohidramnion, kondisi ini akan mempengaruhi janin karena sedikitnya volume air ketuban akan menyebabkan tali pusat tertekan oleh bagian tubuh janin akibatnya aliran darah dari ibu ke janin berkurang sehingga bayi mengalami hipoksia atau gangguan pertukaran oksigen (O2) hingga fetal distress dan berlanjut menjadi asfiksia pada bayi baru lahir.

Asfiksia neonatorum merupakan kegagalan untuk memulai dan melanjutkan pernapasan secara spontan dan teratur pada saat bayi baru lahir atau beberapa saat sesudah lahir (Sukarni, 2014:159). Asfiksia ditandai dengan megap-megap atau tidak menangis secara spontan serta ekstremitas atas dan bawah berwarna agak kebiruan. Penyebab asfiksia dapat terjadi karena banyak faktor, bisa dari faktor ibu, faktor janin, faktor plasenta dan faktor tali pusat. Komplikasi yang terjadi pada faktor ibu dapat menyebabkan terjadinya asfiksia pada bayi baru lahir. Penanganan asfiksia pada bayi baru lahir dapat ditangani secara aktif apabila dengan tenaga kesehatan yang terampil dan professional.

Menurut Prawirohardjo (2008) menyatakan bahwa penyebab kematian maternal dari faktor reproduksi diantaranya adalah usia ibu. Dalam kurun reproduksi sehat dikenal bahwa usia aman untuk kehamilan dan persalinan adalah 20-30 tahun. Kematian ibu pada wanita hamil dan melahirkan pada usia 20 tahun ternyata 2 sampai 5 kali lebih tinggi daripada kematian ibu pada usia 20-30 tahun. Kematian maternal meningkat kembali pada usia 30-35 tahun. Dalam penelitian ini bahwa hampir seluruh ibu bersalin berusia 20-30 tahun, pada usia tersebut merupakan waktu bersalin yang baik, karena merupakan usia reproduksi yang seharusnya tidak menimbulkan komplikasi bagi ibu bersalin itu sendiri. Dari hasil penelitian, terdapat sebagian besar ibu hamil adalah primigravida dan multigravida serta berusia reproduktif, dimana organ telah siap menerima kehamilan dan kondisi yang optimal dan kejadian ketuban pecah dini bisa terjadi pada ibu primigravida atau multigravida. Hal ini disebabkan karena ibu yang berusia reproduktif lebih rentan dan mudah mengalami suatu penyakit atau komplikasi seperti ketuban pecah dini. Hal ini berkaitan dengan kemunduran dan penurunan daya tahan tubuh serta berbagai penyakit yang sering manimpa pada usia reproduktif.

Dari hasil penelitian sebagian besar ibu bersalin mengalami ketuban pecah dini dan hampir setengah bayi yang dilahirkan mengalami asfiksia. Oleh sebab itu kejadian tersebut perlu dilakukan penanganan yang intensif pada ibu bersalin dengan ketuban pecah dini karena bisa menyebabkan terhambatnya suplai oksigen dari ibu ke janin. Tindakan yang dilakukan yaitu menganjurkan ibu bersalin dengan ketuban pecah dini segera masuk ke rumah sakit untuk mendapatkan pengawasan yang konservatif sehingga dapat mengurangi resiko terjadinya asfiksia neonatorum.

\section{Besar Resiko Kejadian Asfiksia Neonatorum Pada Ketuban Pecah Dini Di Rumah Sakit Kalisat Jember}

Hasil perhitungan SPSS menggunakan Odd Ratio (OR) didapatkan nilai sebesar 14,727 yang hasilnya $>1$ berarti ada efek negative yang artinya ibu bersalin dengan KPD 
lebih beresiko 14 kali lipat daripada ibu bersalin yang tidak KPD untuk melahirkan bayi yang asfiksia.

Menurut Prawirohardjo (2008: 679) ketuban pecah dini akan mengakibatkan terjadinya oligohidramnion, kondisi ini akan mempengaruhi janin karena sedikitnya volume air ketuban akan menyebabkan tali pusat tertekan oleh bagian tubuh janin akibatnya aliran darah dari ibu ke janin berkurang sehingga bayi mengalami hipoksia atau gangguan pertukaran oksigen (O2) hingga fetal distress dan berlanjut menjadi asfiksia pada bayi baru lahir. Adapun pendapat lainnya menurut Rahmawati (2011:130) yang menyatakan bahwa ketuban pecah dini yang tidak dilakukan tindakan dengan cepat dapat menimbulkan resiko infeksi yang disebabkan karena tidak ada perlindungan dari dunia luar dengan daerah rahim sehingga mempermudah masuknya mikroorganisme ke dalam rahim. Saat hal itu terjadi maka ketika bayi baru lahir dapat mengakibatkan terjadinya asfiksia.

Berdasarkan hasil dari penelitian yang didapatkan menyatakan bahwa ketuban pecah dini merupakah salah satu faktor dari ibu yang dapat menyebabkan resiko terjadinya komplikasi dalam persalinan. Apabila ketuban pecah dini tidak ditangani dengan cepat maka akan terjadi komplikasi persalinan yang dapat meningkatkan resiko terjadinya asfiksia pada bayi baru lahir. Ketuban pecah dini dapat menimbulkan terjadinya infeksi pada saat persalinan dimana dapat ditimbulkan dari lamanya proses terjadinya ketuban pecah dini. Semakin lama ketuban pecah dini terjadi maka semakin besar resiko terjadinya asfiksia pada bayi baru lahir. Semakin lambat tindakan pada ketuban pecah dini maka akan bisa meningkatkan asfiksia pada bayi lahir pula.

Berdasarkan hasil penelitian hampir setengah jumlah dari ibu bersalin dengan ketuban pecah dini melahirkan bayi dengan keadaan asfiksia. Asfiksia neonatorum dapat diakibatkan dari berbagai macam komplikasi pada ibu, itu juga dikarenakan berbagai faktor. Jadi, ibu bersalin dengan ketuban pecah dini dianjurkan untuk segera memeriksakan diri ke rumah sakit, agar dapat mendeteksi atau mencegah sedini mungkin akan terjadinya komplikasi pada janin seperti asfiksia pada bayi baru lahir.

\section{Kesimpulan Dan Saran}

Kesimpulan

Dari hasil penelitian diatas maka dapat diambil kesimpulan sebagai berikut:

1. Sebagian besar bayi baru lahir tidak mengalami asfiksia di Rumah Sakit Kalisat Jember
2. Sebagian besar ibu bersalin tidak mengalami KPD di Rumah Sakit Kalisat Jember

3. Ada hubungan antara ketuban pecah dini dengan asfiksia neonatorum di Rumah Sakit Kalisat Jember.

4. Ada resiko kejadian asfiksia neonatorum pada ketuban pecah dini sebesar 14 kali lipat di Rumah Sakit Kalisat Jember.

Saran

Saran yang dapat diberikan oleh peneliti dari kesimpulan diatas adalah sebagi berikut:

1. Bagi institusi pendidikan diharapkan dapat menambah dan mengembangkan ilmu pengetahuan dan memberikan informasi kepada masyarakat mengenai persalinan dengan ketuban pecah dini (KPD) yang dapat beresiko menyebabkan asfiksia pada bayi baru lahir.

2. Bagi Rumah sakit diharapkan dapat memberikan penanganan ibu bersalin yang mengalami ketuban pecah dini (KPD) dan melakukan KIE mengenai dampak terjadinya asfiksia pada bayi baru lahir salah satunya ketuban pecah dini (KPD).

3. Bagi petugas kesehatan diharpkan tenaga kesehatan semakin intensif dalam menangani ibu bersalin dengan ketuban pecah dini (KPD) sehingga kejadian asfiksia neonatorum dapat dikurangi.

\section{Daftar Pustaka}

Cunningham, G. 2006. Obstetri William vol.1. Jakarta: EGC.

Dewi, Vivian Nanny Lia. 2014. Resusitasi Neonatus. Jakarta: Salemba Medika.

Dinkes, 2015. Profil kesehatan Provinsi Jawa Timur Tahun 2015.

Icesmi Sukarni, dkk. 2014. Patologi: kehamilan, persalinan, nifas, dan neonatus resiko tinggi. Yogyakarta: Nuha Medika.

Mochtar, Rustam. 1998. Sinopsis obstetri jilid i edisi 2. Jakarta: EGC.

Prawirohardjo, Sarwono. 2008. IImu kebidanan. Jakarta: PT. Bina Pustaka Sarwono Prawirohardjo.

Prawirohardjo, Sarwono. 2009. Buku acuan nasional pelayanan kesehatan maternal dan neonatal. Jakarta: PT. Bina Pustaka Sarwono Prawirohardjo.

Rahmawati, Eni Nur. 2011. Ilmu praktis kebidanan. Surabaya: Victory Inti Cipta.

Sondakh, Jenny J.S. 2013. Asuhan kebidanan persalinan dan bayi baru lahir. Jakarta: Erlangga. 
